\title{
KEEFEKTIFAN PERAN KOMITE SEKOLAH DASAR NEGERI DI KECAMATAN BANJARMANGU, KABUPATEN BANJARNEGARA
}

\author{
Dhuta Sukmayoga, Muhyadi \\ Swift English School, Universitas Negeri Yogyakarta \\ dhutsy@yahoo.com,muhyadi@uny.ac.id
}

\begin{abstract}
Abstrak
Penelitian ini bertujuan untuk melihat keefektifan dan hambatan dalam pelaksanaan peran komite sekolah sebagai badan pertimbangan, badan pendukung, badan pengawas dan badan peng-hubung di sekolah dasar negeri di Kecamatan Banjarmangu, Kabupaten Banjarnegara. Penelitian ini adalah penelitian deskriptif kualitatif. Lokasi penelitian adalah dua sekolah dasar negeri di Kecamatan Banjarmangu, Kabupaten Banjarnegara, yaitu SDN 1 Banjarmangu dan SDN 3 Kesenet. Pengumpulan data menggunakan angket dan melalui wawancara. Pemeriksaan keabsahan data menggunakan triangulasi sumber. Penelitian ini menunjukkan hasil bahwa secara umum, peran komite sekolah SDN di Kecamatan Banjarmangu cukup efektif. Komite sekolah di daerah perkotaan lebih efektif daripada komite sekolah di daerah pedesaan. Kendala Komite Sekolah SDN di Kecamatan Banjarmangu dalam menjalankan perannya adalah rendahnya kompetensi pengurus, kesadaran dan motivasi pengurus, dan kurangnya dana operasional.
\end{abstract}

Kata kunci: komite sekolah, peran komite sekolah, keefektifan peran

\section{ELEMENTARY SCHOOL COUNCIL EFFECTIVENESS IN BANJARMANGU DISTRICT BANJARNEGARA REGENCY}

\begin{abstract}
This research aims to see the effectiveness and the barriers in the implementation of school council roles as advisory body, supporting body, controlling body, and mediating body in elementary schools in the District of Banjarmangu, Banjarnegara Regency. This research was descriptive qualitative. The location of the research was two public elementary schools in Banjarmangu District, Banjarnegara Regency, i.e SDN 1 Banjarmangu and SDN 3 Kesenet. The data collecting methods were questionnaires and interviews. The data validation method was source triangulation. The results of the research show that the role effectiveness of school councils in all elementary schools in Banjarmangu District is 'effective enough'. The school councils in urban areas are more effective than those in the rural areas. The main barrier in implementing the roles is the lack of competence, awareness and moti-vation as well as the short of operational funds.
\end{abstract}

Keywords: school council, school council roles, role effectiveness 


\section{Pendahuluan}

Dinamika tata kelola pemerintahan telah menempatkan otonomi menjadi acuan dalam membangun suatu bangsa dan negara. Maka desentralisasi merupakan unsur yang sangat penting dalam membangun suatu negara yang berdaulat. Tentu saja manajemen pemerintahan ini memberi pengaruh bagi manajemen pendidikan nasional. Desentralisasi pendidikan mendorong semua pihak di daerah untuk lebih menunjukkan keterlibatannya dalam membangun pendidikan di daerahnya agar mampu menghasilkan pendidikan yang bermutu.

Namun, masyarakat masih banyak yang beranggapan bahwa pendidikan menjadi tanggung jawab sekolah secara penuh. Padahal sesuai dengan perundangundangan yang berlaku, pendidikan juga menjadi tanggung jawab keluarga dan masyarakat secara bersama. Masyarakat merupakan stakeholder yang mempunyai kepentingan atas keberhasilan pendidikan di sekolah, baik pendidikan dasar maupun menengah. Untuk mempermudah hubungan antara sekolah dan masyarakat, diperlukan suatu lembaga yang mampu menjadi penghubung, yaitu Dewan Pendidikan untuk tingkat kabupaten/kota dan provinsi, dan Komite Sekolah untuk tingkat satuan pendidikan.

Pena (2000, p.69) menyebutkan, "Those schools that favor the involvement of parents outperform schools with little parent involvement." Sekolah yang banyak melibatkan orang tua mengalahkan sekolah dengan sedikit keterlibatan orang tua. Keterlibatan orang tua memberikan sumber daya yang berharga dalam hal waktu dan dukungan pada sekolah khususnya dengan memasukkan orang tua ketika membuat program sekolah.

Enco Mulyasa (2011, pp.27-28) mengungkapkan bahwa diperlukan partisipasi masyarakat dan hal ini merupakan salah satu aspek dalam manajemen berbasis sekolah. Orang tua dan masyarakat memerlukan wadah untuk dapat berpartisipasi dalam pembuatan berbagai kepu- tusan. Scherer (1994, p.6) mengungkapkan "...parent involvement is a natural area for school boards and educators to work together for the improvement of children's education".

Keterlibatan orang tua adalah tempat bagi komite sekolah dan pendidik untuk bekerja bersama demi peningkatan pendidikan anak. Organisasi yang diharapkan mampu untuk menampung seluruh aspirasi dan peran serta masyarakat tersebut adalah Komite Sekolah. Northen Ireland Assembly (2011), meneliti Komite Sekolah (School Council) di beberapa sekolah di Irlandia Utara dengan kesimpulan bahwa terlihat jelas bahwa School Council mempunyai potensi besar untuk memberikan pengaruh yang positif untuk siswa dan untuk sekolah. Komite Sekolah merupakan badan atau lembaga nonprofit dan nonpolitis, yang dibentuk berdasarkan musyawarah secara demokratis oleh stakeholder pendidikan pada tingkat satuan pendidikan, sebagai representasi dari berbagai unsur yang bertanggung jawab terhadap peningkatan kualitas, proses dan hasil pendidikan.

Masalahnya adalah bahwa kemampuan atau kompetensi SDM Komite Sekolah masih rendah. Dari hasil pengamatan awal di beberapa sekolah dasar negeri di Banjarmangu, yaitu SDN 1 Banjarmangu dan SDN 3 Kesenet, Komite Sekolah di daerah ini banyak yang hanya lulusan SD. Hal ini bisa berpengaruh terhadap performa Komite Sekolah. Seringkali anggota Komite Sekolah tidak mampu melaksanakan perannya dengan baik.

Selain itu pemahaman masyarakat mengenai peran dan fungsi Komite Sekolah juga masih rendah. Kondisi umum di lapangan, Komite Sekolah masih dipersepsikan sebagai lembaga sekolah yang fungsinya terbatas pada pengumpulan dana pendidikan dari orang tua siswa saja. Di antara masalah yang terkait hal terse-but adalah masih ada Komite Sekolah yang mewarisi pola-pola BP3, sehingga hanya namanya yang berubah. Timbul kesan yang negatif terhadap keberadaan Komite Sekolah di masyarakat. Setelah dibentuk Komite Sekolah, iuran siswa malah naik 
karena sebagian dipakai biaya operasional Komite Sekolah serta program kerja yang belum jelas. Terkesan meniru kepemimpinan birokrat, Komite Sekolah hanya dijadikan stempel oleh kepala sekolah. Padahal, Komite Sekolah memiliki kerja yang berbeda dengan kepala sekolah. Mengelola pendidikan memang tidak semudah membalikkan telapak tangan, tetapi perlu waktu dan proses yang panjang. Di sinilah kinerja Komite Sekolah dipertaruhkan kepada masyarakat sebagai pemilik sejati pendidikan

Adams \& Eccles (2001) menunjukkan bahwa pengurus Komite Sekolah tidak mengetahui dengan pasti peran mereka yang berarti bahwa terdapat kebingungan dan ketidakjelasan mengenai peran Komite Sekolah.

Menurut Siti Irene Dwiningrum (2011, p.32) prasyarat keberhasilan MBS meliputi a) dukungan dan sikap antusias dari seluruh anggota Komite Sekolah untuk ikut berperan serta sebagai mitra sekaligus kelompok kontrol atas kinerja manajemen sekolah.

Pembentukan Komite Sekolah yang hanya ditunjuk oleh Kepala Sekolah dan juga pemahaman dan antusias masyarakat terhadap Komite Sekolah yang rendah menjadikan Komite Sekolah tidak berfungsi sebagaimana mestinya khususnya dalam menjalankan perannya seperti dijelaskan Hasbullah (2006, pp.92-93) sebagai; (a) memberikan pertimbangan (advisory agency); (b) memberikan dukungan (supporting agency); (c) mengawasi penyelenggaraan pendidikan di sekolah (controlling agency); (d) penghubung antara sekolah dengan orang tua siswa dan stakeholders lainya (mediator).

Salah satu fungsi Komite Sekolah adalah melakukan kontrol sosial dan transparansi anggaran serta akuntabilitas penggunaan anggaran. Di beberapa sekolah, masih ada proyek-proyek rehabilitasi dan pembuatan gedung sekolah yang masih dikelola pihak sekolah, padahal sudah memiliki Komite Sekolah. Akibatnya, karena tidak dilibatkan dalam proses pembangunan dan penyusunan RAPBS, hubungan Komite Sekolah dengan pihak sekolah pun menjadi tidak harmonis. Peran Komite Sekolah adalah sebagai pemberi pertimbangan dan masukan dalam penentuan dan pelaksanaan kebijakan pendidikan. Juga sebagai pendukung, baik yang berwujud finansial, pemikiran mau-pun tenaga, dalam upaya memajukan sekolah secara bersama-sama. Keberhasilan pendidikan bukan hanya memerlukan peran guru, tetapi juga masyarakat yang diwakili Komite Sekolah juga perlu dilibatkan.

Untuk menjalankan perannya, Komite Sekolah memiliki fungsi mendorong tumbuhnya perhatian dan komitmen masyarakat terhadap penyelenggaraan pendidikan yang bermutu. Secara kelembagaan, Komite Sekolah langsung dapat diawasi oleh masyarakat. Posisi kepala sekolah bukan sebagai pembina, tetapi sejajar dengan Komite Sekolah dan bermitra dalam tata kerja di sekolah. Begitu pun Komite Sekolah, memiliki tugas mendorong orang tua dan masyarakat agar berpartisipasi dalam pendidikan, serta menggalang atau menggali potensi-potensi dana masyarakat untuk pembiayaan penyelenggaraan pendidikan di sekolah tersebut. Oleh karena itu, keberadaan komite harus benar-benar diberdayakan di setiap sekolah. Jika Komite Sekolah sudah berjalan optimal sesuai fungsi dan perannya, organisasi ini akan benar-benar memberikan manfaat yang besar terhadap sekolah.

Masalah lain yang terjadi adalah bahwa belum ada instrumen formal yang digunakan untuk mengevaluasi Komite Sekolah secara rutin layaknya evaluasi terhadap kepala sekolah dalam Penilaian Kinerja Kepala Sekolah (PKKS). Dalam kerangka MBS ada tiga pilar utama yaitu kurikulum yaitu PAIKEM, kepemimpinan yaitu kepala sekolah dan peran masyarakat dalam wadah Komite Sekolah. Ada evaluasi rutin untuk kurikulum dan juga kepala sekolah akan tetapi tampaknya Komite Sekolah kurang mendapatkan perhatian dalam hal ini. Tidak ada evaluasi formal rutin terhadap Komite Sekolah padahal seharusnya sebagai salah satu pilar 
MBS, Komite Sekolah perlu mendapat perhatian lebih salah satunya dengan adanya evaluasi rutin seperti Penilaian Kinerja Kepala Sekolah untuk mengevaluasi kepala sekolah. Sejauh ini evaluasi yang terjadi hanyalah bersifat normatif yang tentu saja tidak formal dan ilmiah.

Berdasarkan latar belakang di atas, ditemukan beberapa masalah sehubungan dengan Komite Sekolah yaitu; (1) Pembentukan Komite Sekolah belum sesuai acuan.

(2) Pemahaman masyarakat mengenai Komite Sekolah masih rendah. (3) Kemauan atau antusias masyarakat mengenai Komite Sekolah masih rendah. (4) Kemampuan dan kemauan para pengurus Komite Sekolah belum memadai. (5) Peran Komite Sekolah di beberapa SD di Banjarmangu sebagai pemberi pertimbangan, sebagai pendukung sebagai pengawas dan sebagai penghubung belum maksimal. (6) Belum ada evaluasi rutin terhadap Komite Sekolah.

Berdasarkan identifikasi masalah di atas, masalah dalam penelitian ini dibatasi pada masalah yang berhubungan dengan peran Komite Sekolah serta evaluasinya yaitu (1) Peran Komite Sekolah di beberapa SD di Banjarmangu sebagai pemberi pertimbangan, sebagai pendukung sebagai pengawas dan sebagai peng-hubung belum maksimal. (2) Belum ada evaluasi rutin terhadap Komite Sekolah.

Berdasarkan identifikasi masalah dan pembatasan masalah maka rumusan masalah dalam penelitian ini adalah sejauh mana keefektifan peran Komite Sekolah di Sekolah Dasar Negeri 1 Banjarmangu Kecamatan Banjarmangu Kabupaten Banjarnegara. Dan sejauh mana keefektifan peran Komite Sekolah di Sekolah Dasar Negeri 1 Kesenet Kecamatan Banjarmangu Kabupaten Banjarnegara.

Penelitian ini dimaksudkan untuk mengungkapkan bagaimana kondisi dan pelaksanaan peran Komite Sekolah sebagai pemberi pertimbangan, sebagai pendukung, sebagai pengawas, dan sebagai penghubung di SDN 1 Banjarmangu dan SDN 3 Kesenet. Penelitian ini juga ditujukan sebagai salah satu bentuk evaluasi terhadap peran Komite Sekolah sehingga bisa diketahui tingkat keefektifan peran Komite Sekolah di SDN 1 Banjarmangu dan SDN 3 Kesenet.

Manfaat Penelitian

Dengan mendasarkan pada rumusan masalah yang dianalisis, maka hasil penelitian diharapkan dapat mem-berikan manfaat baik secara teoritis mau-pun praktis.

\section{Manfaat Teoritis}

Hasil penelitian ini dapat dijadikan sebagai bahan kajian lebih lanjut dalam rangka perencanaan pendidikan dan pengembangan implementasi MBS demi tercapainya mutu pendidikan yang diharapkan. Di samping itu juga hasil penelitian ini akan memberikan kontribusi terhadap perkembangan dan pemberdayaan sumber daya pendidikan, Komite Sekolah pada khususnya.

\section{Manfaat Praktis}

Sebagai bahan masukan kepada Dewan Pendidikan dalam rangka pembinaan terhadap Komite Sekolah berkaitan dengan perannya sebagai badan pemberi pertimbangan, pendukung, pengawas dan penghubung di satuan pendidikan khususnya di Kecamatan Banjarmangu Kabupaten Banjarnegara beserta evaluasinya.

Bahan masukan kepada kepala sekolah dalam rangka peningkatan fungsi manajemen berkaitan dengan kerja samanya dengan Komite Sekolah.

\section{Metode Penelitian}

Jenis Penelitian

Penelitian ini merupakan penelitian deskriptif dengan pendekatan campuran kuantitatif dan kualitatif. Penelitian ini dilakukan untuk mengetahui keefektifan peran Komite Sekolah yaitu dengan melihat kondisi nyata yaitu keterlaksanaan peran Komite Sekolah untuk kemudian dibandingkan dengan kriteria yang sudah ditetapkan yaitu standar peran Komite Sekolah dari Depdiknas. Dalam penelitian 
ini digambarkan berbagai kondisi dan situasi yang ada atau kondisi kongkret dari objek penelitian sehingga dihasilkan deskripsi tentang objek penelitian secara komprehensif yang kemudian dihubungkan dengan indikator keefektifan Komite Sekolah untuk menentukan keefektifan peran Komite Sekolah.

\section{Tempat dan Waktu Penelitian}

Penelitian ini dilakukan di dua sekolah dasar negeri di Kecamatan Banjarmangu Kabupaten Banjarnegara yaitu SDN 1 Banjarmangu dan SDN 3 Kesenet selama bulan Agustus 2013 sampai dengan Desember 2013. Alasan dipilihnya dua sekolah tersebut adalah bahwa dua sekolah tersebut mempunyai karakteristik yang berbeda. Sekolah Dasar Negeri 1 Banjarmangu merupakan sekolah yang maju dengan fasilitas yang memadai serta sarana prasarana yang lengkap. Sekolah ini berada di desa yang maju dengan industri gerabah dan aluminium sebagai salah satu penggerak ekonomi utama. Sekolah Dasar Negeri 3 Kesenet merupakan sekolah dengan keterbatasan sarana dan prasarana. Infrastruktur di sekitar sekolah ini belum maju. Diharapkan dengan dilakukannya penelitian di dua sekolah dengan karakteristik yang berbeda ini bisa diketahui keefektifan peran Komite Sekolah di dua sekolah dengan karakteristik yang berbeda tersebut.

\section{Subjek dan Objek Penelitian}

Subjek penelitian ini adalah Ketua dan pengurus Komite Sekolah di SDN 3 Kesenet, ketua dan pengurus Komite Sekolah di SDN 1 Banjarmangu, Kepala SDN 3 Kesenet, dan Kepala SDN 1 Banjarmangu.

Guru tidak dimasukkan sebagai subjek penelitian secara tersendiri karena beberapa guru sudah menjadi pengurus Komite Sekolah. Objek penelitian ini adalah aktifitas dari Komite Sekolah yang menunjukkan keterlaksanaan peran Komite Sekolah dilihat dari peran Komite Sekolah sebagi pemberi pertimbangan, pendukung, pengawas dan penghubung.
Teknik Pengumpulan Data

Ada beberapa teknik, cara atau metode yang dilakukan untuk memperoleh data yaitu:

Angket

Angket tersebut digunakan untuk memperoleh data mengenai sejauh mana peran Komite Sekolah telah dilaksanakan menurut masing-masing pengurus Komite Sekolah.

\section{Wawancara}

Wawancara dilakukan pada Kepala Sekolah dan Ketua Komite Sekolah.

\section{Observasi}

Metode ini akan digunakan untuk mendapatkan data-data mengenai kondisi umum lokasi penelitian.

\section{Dokumentasi.}

Metode ini digunakan untuk memperoleh data diantaranya dokumen, foto dan bahan statistik.

Dalam membuat instrumen angket dan pedoman wawancara maupun pedoman observasi dan dokumentasi mengacu pada kisi-kisi pengembangan instrumen yang mengacu pada Modul Pemberdayaan Komite Sekolah yang dikeluarkan oleh Depdiknas pada tahun 2006 yang kemudian diteruskan Dinas Pendidikan Kabupaten Banjarnegara dalam workshop "Revitalisasi Komite Sekolah" pada tahun 2007.

Keabsahan Data

Dalam penelitian ini digunakan triangulasi sumber untuk menjamin keabsahan data yang diperoleh. Triangulasi sumber ini dilakukan dengan cara mendapatkan data dari berbagai sumber atau pihak untuk menjamin keabsahan data. Dalam hal ini, data diambil dari pihak pengurus Komite Sekolah yang di dalamnya terdapat guru yang menjadi pengurus Komite Sekolah, Ketua Komite Sekolah dan kepala sekolah. 
Teknik Analisis Data

Data yang berupa data kualitatif dianalisa dan diolah melalui dua tahapan:

\section{Klasifikasi data}

Proses pengolahan data dalam kegiatan ini mencakup editing, entri data, cleaning data yang telah dikumpulkan dan memasukkannya ke dalam sistem komputer. Hasil dari kegiatan ini adalah data yang siap dianalisis.

\section{Interpretasi data}

Data kualitatif dari wawancara dipahami dan dianalisis dengan menghubungkan dengan indikator yang telah ditentukan. Tujuannya adalah memperoleh gambaran yang jelas mengenai keadaan yang sebenarnya. Dengan cara tersebut diperoleh gambaran mengenai keadaan atau keterlaksanaan peran Komite Sekolah secara lebih mendalam.

\section{Hasil Pembahasan}

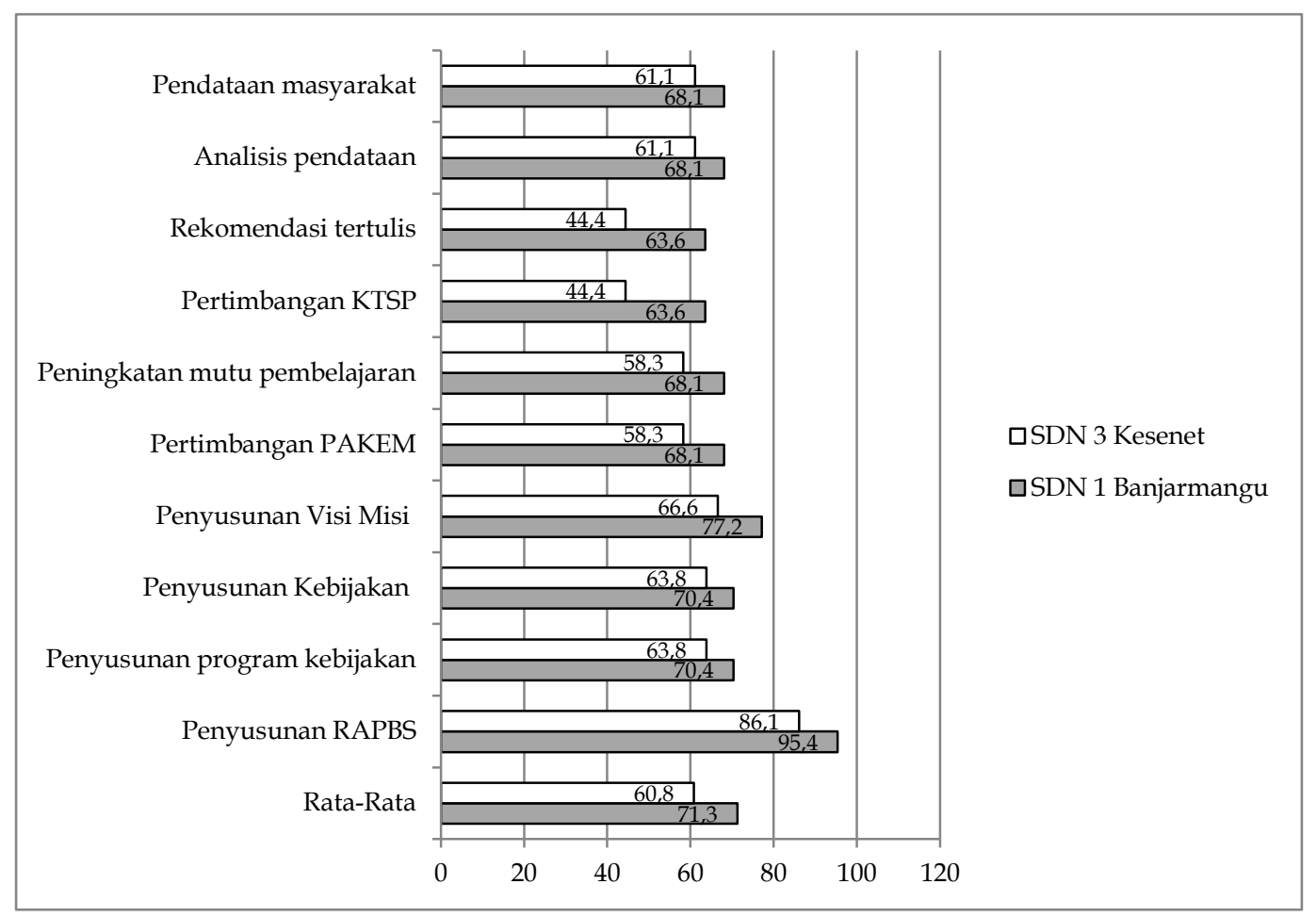

Gambar 1. Keefektifan peran pertimbangan

Di SDN 1 Banjarmangu, Komite Sekolah dalam menjalankan peran sebagai pemberi pertimbangan, Komite Sekolah menjalankan beberapa perannya dengan baik. Peran yang dijalankan paling efektif adalah dalam memberikan pertimbangan dalam penyusunan RAPBS. Peran ini dilaksanakan dalam rapat koordinasi rutin yang memang sudah dijadwalkan. Peran lain yang dijalankan dengan efektif adalah memberikan pertimbangan mengenai visi dan misi, yang juga dilaksanakan dalam rapat rutin. Peran yang dijalankan paling tidak efektif adalah memberikan pertim- bangan dalam hal kurikulum dan pembelajaran. Peran memberikan pertimbangan dalam kurikulum dan pembelajaran tersebut tidak dijadwalkan untuk dilaksanakan secara rutin dalam rapat. Bisa dikatakan beberapa peran yang dilaksanakan dalam rapat dilaksanakan dengan efektif. Sebaliknya, peran yang dijadwalkan secara rutin dalam rapat tidak dilaksanakan dengan efektif.

Hambatan dalam pelaksanaan peran sebagai pemberi pertimbangan terutama adalah yang berkaitan dengan pemberian pertimbangan mengenai kurikulum 
dan pembelajaran yaitu rendahnya kompetensi yang berhubungan dengan kurikulum dan pembelajaran. Hambatan kedua berupa kurangnya kesadaran pengurus untuk melaksanakan perannya terutama yang tidak dijadwalkan dalam rapat. Hal tersebut bisa dilihat dari rendahnya keefektifan peran yang dilakukan di luar rapat rutin.

Peran sebagai pemberi pertimbangan yang dilaksanakan Komite Sekolah SDN 3 Kesenet masih belum efektif. Hanya ada satu indikator peran yang dijalankan dengan efektif yaitu memberikan pertimbangan dalam penyusunan RAPBS. Peran ini dilaksanakan dalam rapat koordinasi rutin yang memang sudah dijadwalkan. Selain peran tersebut, tidak ada peran yang dijalankan dengan efektif. Indikator peran dengan keefektifan terendah adalah memberikan pertimbangan dalam hal kurikulum dan pembelajaran dan memberikan rekomendasi tertulis terhadap sekolah. Peran memberikan pertim- bangan dalam kurikulum dan pembelajaran tersebut tidak dijadwalkan untuk dilaksanakan secara rutin dalam rapat. Sama halnya dengan apa yang terjadi pada Komite Sekolah SDN 1 Banjarmangu, peran yang dilaksanakan dalam rapat dilaksanakan dengan lebih efektif dibandingkan dengan peran yang tidak dijadwalkan secara rutin dalam rapat.

Hambatan dalam pelaksanaan peran sebagai pemberi pertimbangan terutama adalah yang berkaitan dengan pemberian pertimbangan mengenai kurikulum dan pembelajaran yaitu rendahnya kompetensi yang berhubungan dengan kurikulum dan pembelajaran. Hambatan kedua berupa kurangnya kesadaran pengurus untuk melaksanakan perannya terutama yang tidak dijadwalkan dalam rapat. Hal tersebut bisa dilihat dari rendahnya keefektifan peran yang dilakukan di luar rapat rutin.

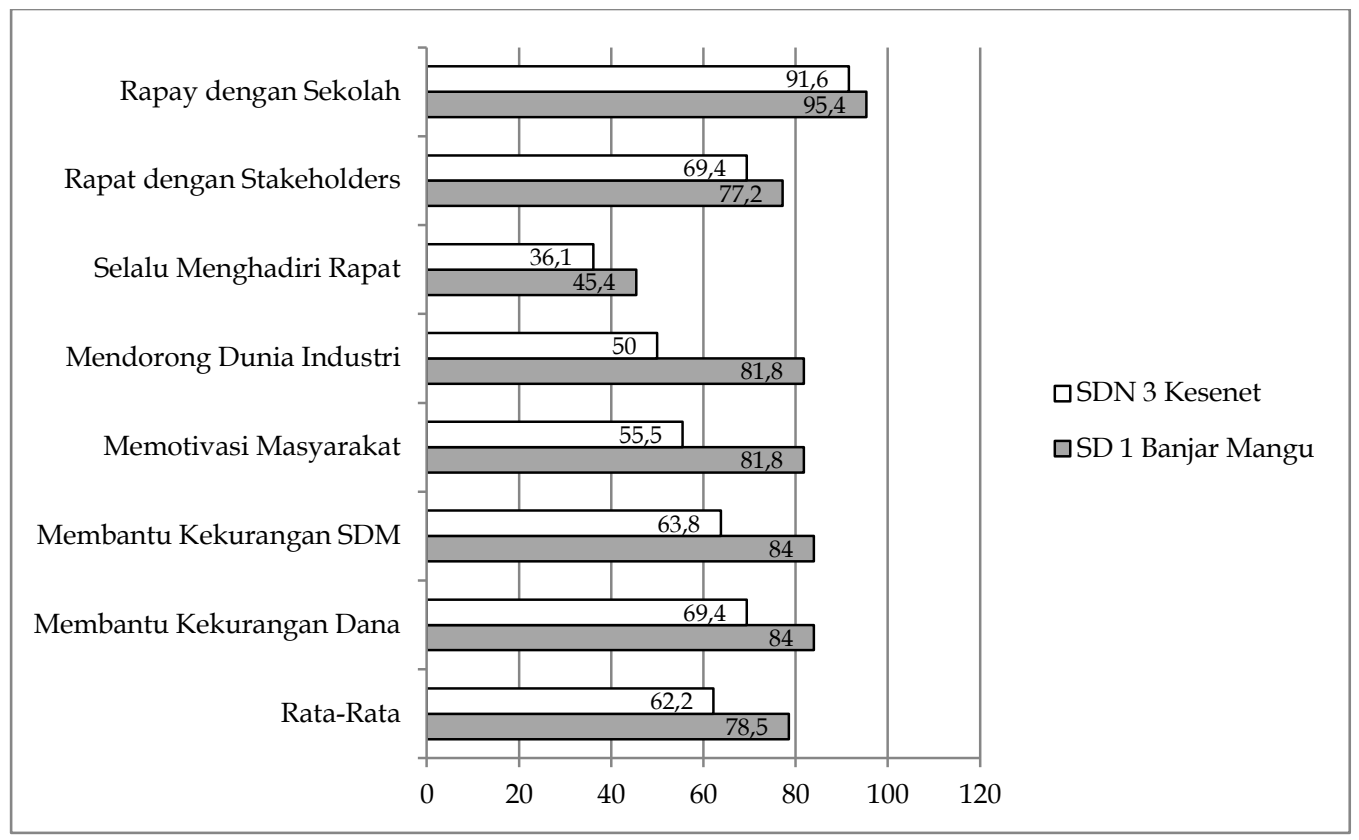

Gambar 2. Keefektifan peran pendukung

Peran sebagai pendukung dilakukan dengan efektif oleh Komite Sekolah SDN 1 Banjarmangu. Indikator peran yang dilaksanakan dengan keefektifan tertinggi adalah diselenggarakannya rapat dengan pihak sekolah. Akan tetapi peran dengan keefektifan terendah menunjukkan bahwa Komite Sekolah tidak selalu menghadiri rapat dengan sekolah. Hal tersebut menunjukkan bahwa walaupun telah dijadwalkan rapat, tetapi tidak semua pengurus Komite 
Sekolah menghadiri rapat yang sudah dijadwalkan.

Empat peran lain yang dilaksanakan dengan efektif adalah membantu kekurangan dana, membantu kekurangan SDM, memotivasi masyarakat dan mendorong peran dunia industri. Keefektifan atau kesuksesan peran tersebut erat kaitannya dengan kondisi masyarakat di sekitar sekolah. Keadaan masyarakat sekitar yang tergolong masyarakat mampu serta adanya beberapa sentra industri membantu terlaksananya peran tersebut dengan mudah.

Hambatan utama dalam pelaksanaan peran sebagai pendukung adalah kurangnya kesadaran pengurus terutama dalam menghadiri rapat yang telah dijadwalkan. Faktor pendorong keefektifan adalah telah berkembangnya masyarakat dan juga adanya sentra industri di sekitar sekolah.

Indikator peran sebagai pendukung yang dilaksanakan Komite SDN 3 Kesenet dengan keefektifan tertinggi adalah dilaksanakannya rapat dengan pihak sekolah. Akan tetapi indikator peran dengan keefektifan terendah menunjukkan bahwa Komite Sekolah tidak selalu menghadiri rapat dengan sekolah. Hal tersebut menunjukkan bahwa walaupun telah dijadwalkan rapat, tetapi tidak semua pengurus Komite Sekolah menghadiri rapat yang sudah dijadwalkan.

Peran lain yaitu membantu kekurangan dana, membantu kekurangan SDM, memotivasi masyarakat dan mendorong peran dunia industri belum efektif. Peran tersebut erat kaitannya dengan kondisi masyarakat di sekitar sekolah. Keadaan masyarakat sekitar yang mayoritas adalah petani dengan ekonomi menengah ke bawah menyebabkan peran tersebut sulit untuk dijalankan. Misalnya masyarakat dengan kondisi ekonomi yang tidak terlalu baik menghambat keterlaksanaan peran untuk membantu kekurangan dana. Selain itu tingkat pendidikan masyarakat juga mempengaruhi kesadaran masyarakat untuk ikut terlibat dalam memajukan pendidikan di sekolah.

Hambatan utama dalam pelaksanaan peran sebagai pendukung adalah kurangnya kesadaran pengurus terutama dalam menghadiri rapat yang telah dijadwalkan. Kesadaran masyarakat setempat untuk terlibat dalam memajukan pendidikan serta kondisi ekonomi yang tidak kondusif juga merupakan faktor penghambat.

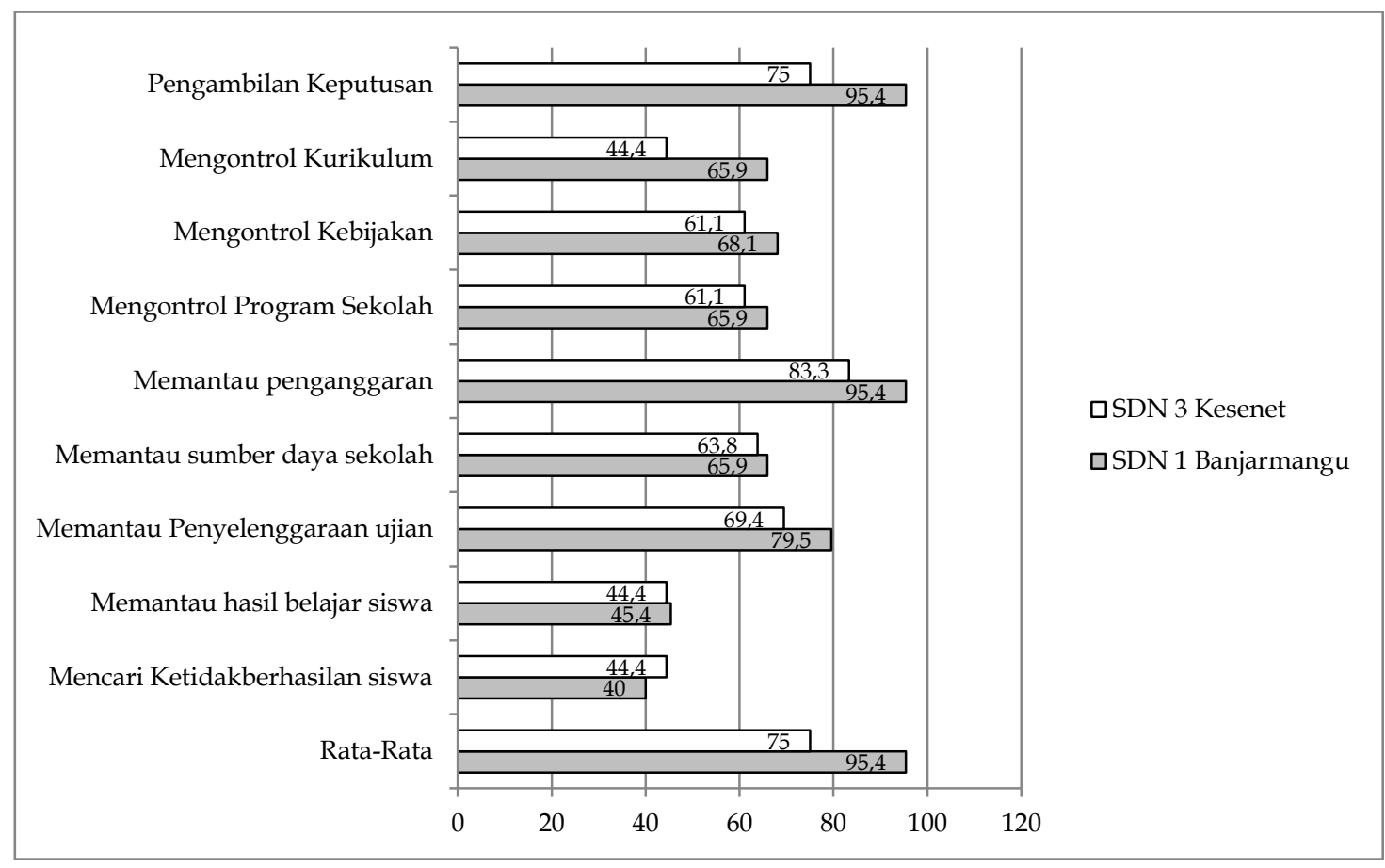

Gambar 3. Keefektifan peran pengawas 
Komite Sekolah menjalankan peran sebagai pengawas dengan cukup efektif. Dua peran yang dilakukan dengan paling efektif adalah mengawasi pengambilan keputusan dan mengawasi penganggaran atau pembiayaan. Peran ini dilaksanakan dalam rapat rutin. Peran yang kurang efektif adalah yang berhubungan dengan kesiswaan yaitu, memantau hasil belajar siswa dan mencari ketidakberhasilan siswa. Peran ini tidak dijadwalkan secara rutin dalam rapat. Keadaan ini menguatkan kesimpulan bahwa peran yang dijadwalkan dan dilaksanakan dalam rapat rutin mempunyai keefektifan lebih tinggi daripada peran yang tidak dilakasankan dalam rapat rutin.

Hambatan utama dalam pelaksanaan peran sebagai pengawas adalah rendahnya kesadaran pengurus Komite Sekolah untuk melaksanakan peran walaupun tidak dijadwalkan secara rutin dalam rapat. Selain itu, kompetensi dalam hal kurikulum dan pembelajaran juga merupakan faktor rendahnya keefektifan peran dalam mengawasi kurikulum dan pembelajaran.

Komite Sekolah SDN 3 Kesenet menjalankan peran sebagai pengawas dengan cukup efektif. Dua peran yang dilakukan dengan paling efektif adalah mengawasi pengambilan keputusan dan mengawasi penganggaran atau pembiayaan. Peran ini dilaksanakan dalam rapat rutin.
Peran dengan tingkat keefektifan terendah adalah yang berhubungan dengan kesiswaan yaitu, memantau hasil belajar siswa dan mencari ketidakberhasilan siswa. Peran ini tidak dijadwalkan secara rutin dalam rapat. Bisa dikatakan bahwa peran yang dijadwalkan dan dilaksanakan dalam rapat rutin mempunyai keefektifan lebih tinggi daripada peran yang tidak dilaksanakan dalam rapat rutin.

Hambatan utama dalam pelaksanaan peran sebagai pengawas adalah rendahnya kesadaran pengurus Komite Sekolah untuk melaksanakan peran walaupun tidak dijadwalkan secara rutin dalam rapat. Selain itu, kompetensi dalam hal kurikulum dan pembelajaran juga merupakan faktor rendahnya keefektifan peran dalam mengawasi kurikulum dan pembelajaran.

Dari enam indikator peran, terdapat dua indikator peran yang berada dalam kategori kurang efektif yaitu memberi laporan kepada masyarakat dan penjagaan kemungkinan kerja sama. Peran yang paling efektif adalah menampung dan menganalisis aspirasi, ide, tuntutan dan berbagai kebutuhan pendidikan masyarakat. Menurut kepala sekolah, peran ini dilaksanakan ketika ada rapat wali murid. Hal tersebut menunjukkan bahwa rapat rutin merupakan salah satu faktor dalam meningkatkan keefektifan suatu peran.

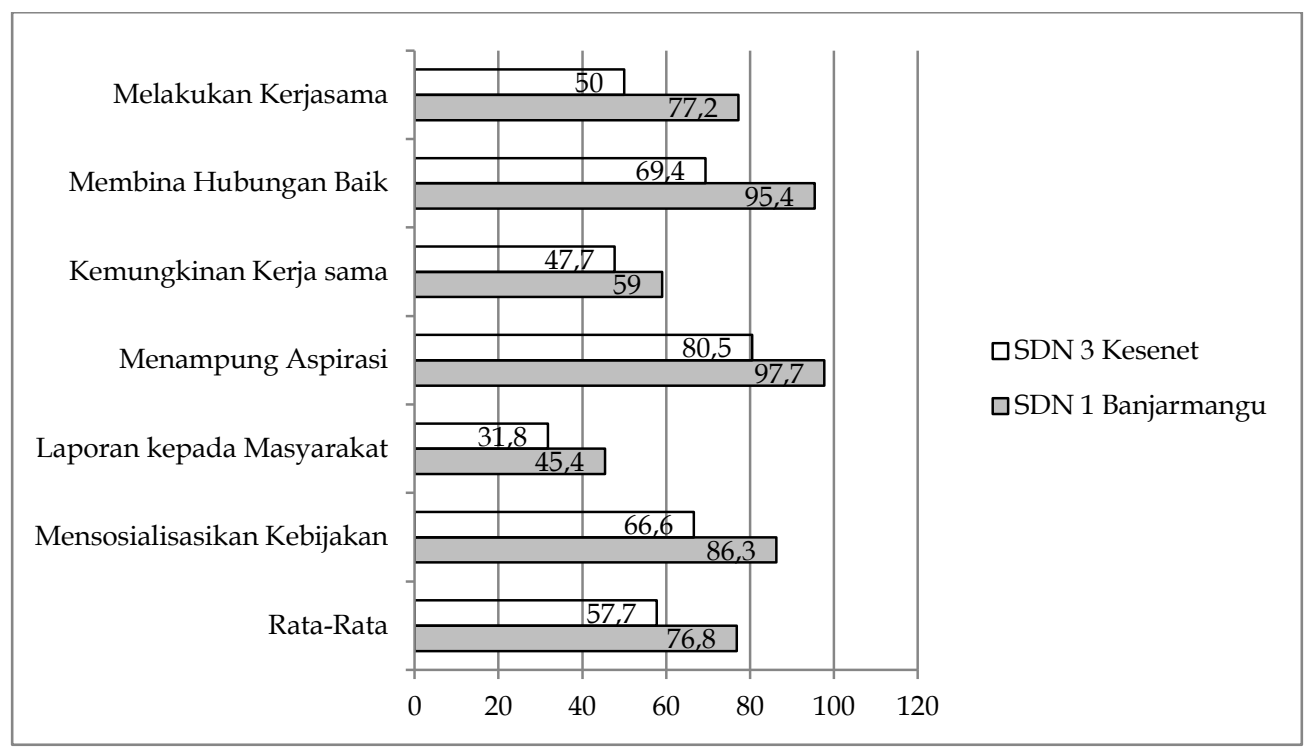

Gambar 4. Keefektifan peran penghubung 
Peran sebagai penghubung dilaksanakan dengan efektif oleh Komite Sekolah SDN 1 Banjarmangu. Dari enam indikator peran, hanya dua peran yang belum efektif yaitu memberi laporan kepada masyarakat dan penjagaan kemungkinan kerja sama. Peran yang paling efektif adalah menampung dan menganalisis aspirasi, ide, tuntutan dan berbagai kebutuhan pendidikan masyarakat. Menurut kepala sekolah, peran ini dilaksanakan ketika ada rapat wali murid. Hal tersebut menunjukkan bahwa rapat merupakan salah satu faktor dalam meningkatkan keefektifan suatu peran.

Faktor utama pendorong keeefektifan peran sebagai penghubung adalah faktor eksternal yaitu kondisi masyarakat yang telah maju pemikirannya. Dunia industri yang telah berkembang di sekitar sekolah juga merupakan faktor pendorong yang paling tidak meningkatkan kemungkinan terlaksananya peran sebagai penghubung dengan efektif.

Peran sebagai penghubung erat kaitannya dengan kondisi masyarakat dan dunia usaha di sekitar sekolah. Kondisi masyarakat bisa menjadi faktor pendorong tetapi juga bisa menjadi faktor penghambat. Masyarakat yang maju dengan perekonomian yang baik seperti yang terjadi di SDN 1 Banjarmangu bisa menjadi faktor pendorong keefektifan peran sebagai penghubung. Sementara di SDN 3 Kesenet, keadaan masyarakat yang belum terlalu maju menjadikannya sebagai faktor penghambat keeefektifan peran sebagai penghubung, salah satunya bisa dilihat dari rendahnya indikator peran dalam hal membina kerja sama.

Secara keseluruhan bisa disimpulkan beberapa hal berkaitan dengan keefektifan peran Komite Sekolah di SDN 1 Banjarmangu dan SDN 3 Kesenet yaitu, 1) peran yang dijadwalkan untuk dilaksanakan dalam rapat koordinasi rutin mempunyai tingkat keefektifan yang lebih tinggi daripada peran yang tidak dilaksanakan dalam rapat koordinasi rutin, 2) kondisi ekonomi dan sosial masyarakat di sekitar sekolah memberi pengaruh terhadap ke- efektifan peran Komite Sekolah khususnya sebagai pendukung dan penghubung, 3) hambatan utama dalam pelaksanaan peran Komite Sekolah adalah tingkat kompetensi pengurus yang belum memadai khususnya dalam hal kurikulum dan pembelajaran, 4) tingkat kesadaran dan motivasi pengurus dalam melaksanakan perannya merupakan hambatan dalam pelaksanaan peran Komite Sekolah.

Penelitian ini memperkuat hasil dari penelitian Whitty \& Wisby (2007) dari Institute of Education, University of London yang menujukkan bahwa rapat adalah hal yang krusial dalam pelaksanaan peran Komite Sekolah. Hal lain yang diperkuat oleh penelitian ini adalah bahwa Komite Sekolah seringkali mempunyai motivasi dan partisipasi yang rendah seperti yang juga ditunjukkan oleh penelitian dari Whitty \& Wisby.

\section{Simpulan dan Saran}

Simpulan

Atas dasar pembahasan di atas, maka simpulan dan implikasi yang perlu diperhatikan oleh pihak-pihak yang berwenang adalah sebagai berikut :

Peran sebagai pemberi pertimbangan Komite Sekolah SDN 1 Banjarmangu berada dalam kategori cukup efektif yang berarti masih bisa ditingkatkan lagi untuk menjadi efektif atau sangat efektif yaitu dengan meningkatkan kesadaran dan kompetensi pengurus Komite Sekolah.

Komite Sekolah SDN 1 Banjarmangu efektif menjalankan perannya sebagai pendukung oleh karenanya perlu untuk mempertahankan dan meningkatkan lagi keefektifan Komite Sekolah sebagai pendukung agar mencapai kategori sangat efektif.

Komite Sekolah SDN 1 Banjarmangu cukup efektif menjalankan perannya sebagai pengawas tetapi mempunyai kesenjangan yang besar terutama dikarenakan rendahnya kesadaran dan kompetensi pengurus. Oleh karenanya diperlukan pelatihan atau workshop untuk me- 
ningkatan kesadaran dan kompetensi pengurus.

Komite Sekolah SDN 1 Banjarmangu efektif menjalankan perannya sebagai penghubung tetapi mempunyai kesenjangan yang besar terutama dikarenakan dana operasional. Oleh karenanya diperlukan penambahan alokasi dana operasional.

Komite Sekolah SDN 3 Kesenet cukup efektif menjalankan perannya sebagai pemberi pertimbangan tetapi mempunyai ke-senjangan yang besar bahkan mendekati batas kurang efektif terutama dikarenakan rendahnya kesadaran dan kompetensi pengurus. Oleh karenanya diperlukan peningkatan kesadaran dan kompetensi pengurus.

Komite Sekolah SDN 3 Kesenet cukup efektif menjalankan perannya sebagai pendukung tetapi mempunyai kesenjangan yang cukup besar terutama dikarenakan rendahnya kesadaran dan kompetensi pengurus. Oleh karenanya diperlukan peningkatan kesadaran dan kompetensi pengurus.

Komite Sekolah SDN 3 Kesenet cukup efektif menjalankan perannya sebagai pengawas, dengan masalah utama rendahnya kesadaran dan kompetensi pengurus. Oleh karenanya diperlukan peningkatan kesadaran dan kompetensi pengurus.

Komite Sekolah SDN 3 Kesenet cukup efektif menjalankan perannya sebagai penghubung tetapi mempunyai kesenjangan yang sangat besar bahkan mendekati batas kurang efektif terutama dikarenakan rendahnya dana operasional. Oleh karenanya diperlukan penambahan alokasi dana operasional.

Komite Sekolah SDN di Kecamatan Banjarmangu di daerah perkotaan lebih efektif dibandingkan Komite Sekolah di daerah pedesaan oleh karenanya Komite Sekolah di daerah pedesaan perlu lebih diperhatikan lagi.

Secara umum, masalah yang dihadapi Komite Sekolah baik di perkotaan maupun di pedesaan sama yaitu rendahnya kompetensi pengurus, kesadaran dan motivasi pengurus serta kurangnya dana operasional. Hal tersebut memberikan pe- doman bagi pihak yang berwenang untuk memperbaikinya.

Saran

Berdasarkan simpulan di atas maka dapat diberikan saran yaitu agar peran Komite Sekolah lebih optimal, perlu diadakan pelatihan Komite Sekolah dengan mengkhususkan pada kompetensi dalam hal kurikulum dan pembelajaran, dengan dibentuk tim khusus dari dikpora sebagai pelatih.

Tidak ada standar kerja yang jelas dan mendetail yang menyebabkan ketidakjelasan kinerja Komite Sekolah, oleh karenanya perlu disusun standar kerja yang jelas dan mendetail.

Standar kerja Komite Sekolah hendaknya dibedakan antara Komite Sekolah di SD, SMP, dan SMA mengingat kerumitan dan kekompleksan perannya juga berbeda. Karena, dengan komposisi organisasi minimal dalam Komite Sekolah SD akan kesulitan memenuhi tuntutan standar peran Komite Sekolah di SMA.

Pemerintah perlu mengalokasikan dana operasional lebih untuk bisa menggerakkan Komite Sekolah mengingat keterbatasan dana adalah salah satu masalah yang dihadapi.

Perlu dibentuk tim untuk mengevaluasi kinerja Komite Sekolah secara rutin dan sistematis layaknya terhadap kepala sekolah seperti dalam Penilaian Kinerja Kepala Sekolah (PKKS).

\section{Daftar Pustaka}

Adams, J., \& Eccles, M. (2001). Working through conflict on school council. York University, Toronto: Schulich School of Business.

Enco Mulyasa. (2011). Manajemen berbasis sekolah. Bandung: Remaja Rosdakarya Offset

Hasbullah. (2006). Otonomi pendidikan, kebijakan otonomi daerah dan implikasinya terhadap penyelenggaraan pendidikan. Jakarta: PT Raja Grafindo Persada 
Northern Ireland Assembly. (2011). School councils. Northern Ieland Assemby: Research and Informastion Service.

Pena, D. (2000). Parent Involvement: Influencing Faktors and Implications. The Journal of Educational Research. Hlm 87-122

Scherer, R. D., \& Scherer, W. L. D. (1994). Do school boards encourage parent involvement? The Journal of Educational Research. Hlm 2-13

Siti Irene Astuti Dwiningrum. (2011). Desentralisasi dan partisipasi masya- rakat dalam pendidikan: suatu kajian teoritis dan empirik. Yogyakarta: Pustaka Pelajar.

Suparlan. (2009). Komite sekolah: kondisi, masalah, dan tantangan di masa depan. Artikel diambil 20 Oktober 2011 dari www.suparlan.com

Whitty, G., \& Wisby, E. (2007). Real decision making? School councils in action. London: Institute of Education, University of London. 